Vol 1 No 12020 Juli 2020

Jurnal AlphaEuclidEdu

Received: 04/07/2020; Revised: 27/07/2020; Accepted: 28/07/2020

\title{
PENGUASAAN MATERI DAN KEMAMPUAN MENULIS PENYELESAIAN SOAL MATEMATIS GURU MATEMATIKA
}

\author{
${ }^{1}$ Tan, Heryanto, ${ }^{2}$ Sugiatno, ${ }^{3}$ Hartoyo, Agung \\ 1,2,3 Pascasarjana Pendidikan Matematika FKIP Universitas Tanjungpura Pontianak \\ heryanto_tan171@yahoo.com
}

\begin{abstract}
Abstact
This research aims to get a description about the mastery of the mathematics materials and the ability in writing the mathematical solution among mathematics teachers of senior high school in Pontianak and the relationship between them. This research is a descriptive research through document and result analysis of Uji Kompetensi Profesional Guru (UKPG) Senior High School in 2016. Materials mastery of mathematics teacher is measured by the final score and understanding of UKPG's selected questions, while the ability in writing mathematical solutions is measured by score of the writing and understanding the writing component in answering all of UKPG's essay questions. Result of this research shows that most teachers got the final score below 55.0. Most mathematics teachers got the score below 47.5 in writing up solution. The higher the mastery of materials, the higher the ability in writing the mathematical solution
\end{abstract}

Keywords : Mastery of mathematics materials, Ability in writing the mathematical solution.

\section{Pendahuluan}

Hasil belajar matematika para peserta didik dipengaruhi oleh banyak faktor, satu di antaranya yaitu faktor penguasaan materi matematika guru itu sendiri. Penguasaan materi matematika guru berkorelasi secara positif dengan hasil belajar peserta didik (Hill, Rowan, dan Ball, 2004; Campbell et al, 2014; Kemdikbud, 2014). Penguasaan terhadap materi pengetahuan (content knowledge) yang akan diajarkan merupakan kemampuan dasar yang mutlak ada pada seorang guru, selain penguasaan terhadap kemampuan pedagogis dan psikologis peserta didik (Shulman dalam Ball dkk, 2008).

Berkaitan dengan matematika, Ball dkk (2008) mengusulkan rincian kategori pengetahuan yang disampaikan Shulman (1986) dan memetakan pengetahuan guru matematika menjadi empat kelompok, yaitu: (1) Pengetahuan matematika wajib (Common Content Knowledge) (CCK), seperti kemampuan berhitung atau penggunaan istilah dan notasi matematika secara tepat. Guru wajib mengetahui dengan baik materi yang akan diajarkan kepada peserta didik atau dengan perkataan lain guru mampu menyelesaikan soal yang ditugaskan kepada peserta didik; (2) Pengetahuan matematika spesifik ( Speciallized Content Knowledge) (SCK), yaitu pengetahuan khusus yang diperlukan guru dalam mengajarkan materi matematika. SCK memerlukan kemampuan pemahaman matematis dan penalaran dalam menguasainya, seperti kemampuan untuk menemukan kecenderungan kesalahan peserta didik atau kemampuan mengecek keabsahan pendekatan yang digunakan peserta; (3) Pengetahuan tentang materi matematika dan peserta didik (Knowledge of Content and Student) (KCS), yaitu pengetahuan tentang karateristik peserta didik dalam belajar matematika, seperti kemampuan mengantisipasi kebingungan atau miskonsepsi yang mungkin dialami peserta didik dalam memahami materi matematika; dan (4) Pengetahuan tentang materi matematika dan pengajaran (Knowledge of Content and Teaching) (KCT), yaitu pengetahuan tentang cara mengajarkan berbagai materi matematika, seperti merancang kegiatan instruksional yang sesuai dengan materi yang akan diajarkan.

Ball dkk (2008) menyebut dua kelompok pengetahuan yang pertama, yaitu CCK dan SCK sebagai pengetahuan subjek materi (subject matter knowledge) dan dua kelompok terakhir, yaitu KCS dan KCT disebut sebagai pengetahuan pedagogis (pedagogical content knowledge). Selain keempat kelompok pengetahuan yang telah diutarakan, Ball dkk (2008) memperkenalkan bahwa pengetahuan lain yang disebut pengetahuan horison (horizon knowledge). Contohnya, guru matematika Kelas 3 mungkin perlu mengetahui hubungan materi yang diajarkan saat ini dengan materi lanjut yang akan dipelajari peserta didik di kelas 5, sehingga dia perlu 
Vol 1 No 12020 Juli 2020

Jurnal AlphaEuclidEdu

menyiapkan dasar yang kuat di Kelas 3 bagi keberhasilan peserta didik dalam memahami dan menguasai materi di Kelas 5.

Menurut National Mathematics Advisory Panel (NMAP) dalam Final Report menekankan guru harus tahu dengan baik materi matematika yang akan diajarkan (NMAP, 2008). Penguasaan materi matematika yang diajarkan di sekolah merupakan kompetensi inti guru matematika dari standar kompetensi profesional yang wajib dimiliki oleh guru, seperti diamanatkan dalam Permendiknas Nomor 16 Tahun 2007. Subjek materi matematika yang harus dikuasai dan diajarkan kepada peserta didik dituangkan dalam dokumen kurikulum yang digunakan. Sesuai Permendikbud Nomor 160 Tahun 2014, Kemdikbud masih memberlakukan dua kurikulum, yaitu Kurikulum Tingkat Satuan Pendidikan (KTSP) 2006 dan KTSP 2013. Ruang lingkup materi yang wajib diajarkan dan dikuasai peserta didik secara nasional disebut standar isi. Standar Isi KTSP 2006 termuat dalam Lampiran Permendiknas Nomor 22 Tahun 2006, sedangkan Standar Isi KTSP 2013 termuat dalam Lampiran Peraturan Menteri Pendidikan dan Kebudayaan (Permendikbud) Nomor 64 Tahun 2013 dan revisinya Permendikbud Nomor 21 Tahun 2016.

Penguasaan materi matematika secara baik akan semakin meningkatkan keyakinan guru akan apa yang akan diajarkan, yang pada pada akhirnya mempengaruhi praktek pembelajaran matematika. Merrilyn Goos dkk (dalam Siswono, 2010) mengungkapkan bahwa keyakinan guru akan matematika memberi pengaruh kuat kepada praktek pengajaran matematika. Kajian Merrilyn Goos dkk ini menjadi tantangan serius pada pembelajaran matematika di Indonesia mengingat fakta yang ditemukan di lapangan seperti masih rendahnya hasil yang dicapai para peserta didik di Programme for International Student Assessment (PISA) dan Ujian Nasional (UN) pada bidang matematika, serta penguasaan materi guru matematika dibeberapa daerah bahkan secara nasional belum ideal.

Penelitian Tatag Yuli Eko Siswono (2010) terhadap 151 orang guru matematika SMA di suatu kota di Jawa Timur yang mengerjakan soal UN Matematika ditemukan sebanyak 49,66\% guru mendapatkan nilai kurang dari 50. Penelitian Fahmi (2011) dari Pusat Penelitian Pendidikan Balitbang Kemdikbud terhadap 283 guru matematika IPA dan 347 guru matematika IPS yang tersebar di 20 provinsi dan 100 kabupaten/kota didapat nilai rata-rata gabungan sebesar 44,64 dengan rincian untuk Program IPA sebesar 35,31 dan untuk Program IPS sebesar 53,97. Penelitian Yulia Lingustika dkk (2013) terhadap 169 SMA/MA yang tersebar diberbagai provinsi menunjukkan penguasaan guru matematika IPA pada materi geometri hanya 32,36\%, penguasaan materi trigonometri sebesar 51,34\%, dan materi kalkulus sebesar 54,79\%. Uji Kompetensi Guru (UKG) yang dilakukan Kemdikbud juga menunjukkan hasil yang belum mengembirakan. UKG Tahun 2015 yang diikuti 2.430.247 guru mengungkapkan kompetensi profesional guru secara nasional hanya pada skor nilai 53,05 (Kemdikbud, 2016). Pusat Pengembangan dan Pemberdayaan Pendidik dan Tenaga Kependidikan (P4TK) Matematika (2016) mengungkapkan nilai rerata hasil UKG Matematika SMA Tahun 2015 adalah sebesar 58,70 .

Nilai UKG dipublikasikan secara umum dan tidak detail. Tidak dipublikasikannya nilai UKG secara detail untuk masing-masing mata pelajaran, tentu membuat pengambil kebijakan di daerah kesulitan mendapatkan dasar berpijak untuk merencanakan dan melaksanakan program peningkatan profesionalisme guru di wilayah masing- masing. Contohnya, program peningkatan profesionalisme melalui forum Musyawarah Guru Mata Pelajaran (MGMP) yang selama ini diprogramkan dan dilaksanakan oleh Dinas Pendidikan Kota Pontianak belum menjadikan hasil UKG sebagai pijakan awal dalam pelaksanaanya akibat tidak rincinya hasil UKG. Dengan keyakinan bahwa penguasaan materi yang baik akan berpengaruh pada proses dan hasil belajar peserta didik, maka Dinas Pendidikan (Dindik) Kota Pontianak memprogramkan kegiatan Uji Kompetensi Profesional Guru (UKPG) Mata Pelajaran UN pada tahun 2016. Untuk mendapat gambaran detail tentang kemampuan guru se-Kota Pontianak, maka analisis terhadap hasil UKPG mutlak dilakukan dan menjadi tujuan pertama dari penelitian ini.

Selain masalah capaian nilai yang belum memuaskan, bentuk soal UN jugai menjadi sorotan. Bentuk soal UN yang berupa soal pilihan berganda tidak menampakkan kemampuan penalaran peserta didik karena hanya 
Vol 1 No 12020 Juli 2020

Jurnal AlphaEuclidEdu

memilih jawaban yang tepat. Kemampuan peserta didik mengungkapkan ide dan penalaran mereka lewat tulisan tidak mendapatkan tempatnya. National Council of Teachers of Mathematics (NCTM) (2000) menyatakan salah satu tujuan pembelajaran matematika adalah peserta didik dapat mengkomunikasikan penalaran matematis mereka secara benar. Menulis sebagai salah satu cara berkomunikasi merupakan bagian tak terpisahkan dalam kurikulum matematika. David Pugalee (2005) menegaskan bahwa menulis mendukung kemampuan penalaran dan penyelesaian masalah para peserta didik dan dapat membantu para peserta didik membangun komunikasi yang efektif (dalam Urquhart, 2007). Para peneliti yang tergabung dalam National Institute for Literacy (NIL) mengatakan bahwa selain meningkatkan kemampuan komunikasi para peserta didik, menulis juga dapat meningkatkan kapasitas belajar dari para peserta didik (dalam Urquhart, 2007).

Menurut Joan Countryman (1992), paling tidak ada empat keuntungan yang didapat dalam kegiatan menulis dalam pembelajaran matematika, yaitu (1) menulis dapat merekam apa yang telah dilakukan dan dipelajari, (2) menulis merupakan cara menjawab soal matematika, (3) menulis merupakan cara mengungkapkan ide - ide matematis, dan (4) menulis dapat mengambarkan proses belajar para peserta didik (dalam Urquhart, 2007). Graham dan Perin (2007) dalam Writing Next mengatakan untuk membantu kemampuan menulis maka guru harus menjadikan kegiatan menulis sebagai bagian dari kegiatan pembelajaran dan menjadikan menulis sebagai alat untuk belajar, termasuk dalam belajar matematika (dalam Urquhart, 2007). Mengingat pentingnya menulis dan kegunaannya, sudah seharusnya guru matematika mempunyai kemampuan menulis yang baik dan benar sehingga dapat menjadi model bagi peserta didik dan menggunakannya dalam mengembangkan pembelajaran matematika.

Sejalan dengan pendapat para praktisi, Muhadjir (2016) selaku Menteri Pendidikan dan Kebudayaan (Mendikbud) di hadapan Komisi X Dewan Perwakilan Rakyat (DPR) pernah mengungkapkan bahwa UN yang bersifat masal dan menggunakan soal pilihan berganda perlu dievaluasi karena kurang mendorong peserta didik untuk mengekspresikan pikiran dan gagasannya. Guna menggali kemampuan peserta didik agar berlatih berpikir kritis dan dapat mengekspresikan gagasannya, maka mulai tahun pelajaran 2016/2017 pihak Kemdikbud menetapkan Ujian Sekolah (US) harus memuat soal uraian. Dengan adanya soal ujian bentuk uraian bagi peserta didik, tentu kemampuan guru di dalam menulis penyelesaian soal matematis atau masalah kontekstual harus sangat memadai.

Selaras dengan paparan, dalam kegiatan UKPG yang telah diprogramkan, Dindik Kota Pontianak telah menetapkan bahwa soal uji kompetensi guru selain berbentuk soal pilihan berganda juga memuat soal uraian. Mencermati kemampuan menulis penyelesaian soal para guru dalam menjawab soal uraian menjadi hal menarik bagi peneliti dan menjadi tujuan kedua dari penelitian ini.

Sebagaimana pernah dialami peneliti sendiri dan peneliti lain, ketidakjelasan dan kesalahan baik pada pernyataan/proposisi ataupun dalam langkah menyelesaikan soal matematika masih kerap muncul pada diri peserta didik manakala menuliskan penyelesaian soal. Ketidakjelasan dalam menuliskan atau mendefinisikan variabel atau menyatakan hasil penyelesaian juga sering terjadi. Kesalahan menuliskan hubungan antar variabel atau kesalahan menuliskan bahasa matematika/relasional dari soal yang dihadapi, kesalahan perubahan bentuk/transformasi hubungan matematis, kesalahan penulisan simbol/indeks/label/rumus (redaksional), bahkan sampai pada kesalahan konsep/miskonsepsi juga masih sering ditemukan pada para peserta didik (Manibuy, Mardiyana, Saputro, 2014; Wibowo, 2016; Arifani, As'ari, Abadyo, 2016).

Guna meminimalkan kesalahan yang sering dipraktekkan oleh peserta didik, guru sebagai model dalam menulis penyelesaian soal, tentunya harus menguasai dengan baik komponen-komponen penulisan penyelesaian soal matematis yang ditugaskan kepada peserta didiknya. Menulis matematika secara baik dan benar bertujuan agar jalan pikiran, jawaban, atau ide penulis dapat dikomunikasikan secara jelas kepada orang lain. Dirangkum dari pendapat beberapa praktisi, paling tidak ada enam komponen dalam penulisan penyelesaian soal matematika sekolah yang harus dikuasai, yaitu : (1) menuliskan fokus dari pertanyaan secara jelas; (2) mendefinisikan variabel yang akan digunakan secara jelas; (3) menuliskan bahasa matematika atau ekspresi matematis dari hubungan/ informasi yang ada secara tepat ; (4) menyajikan gambar atau tabel atau grafik yang 
Vol 1 No 12020 Juli 2020

Jurnal AlphaEuclidEdu

digunakan secara jelas, tepat, dan lengkap; (5) menuliskan langkah-langkah penyelesaian soal secara tepat dan logis; dan (6) menulis kesimpulan jawaban soal yang ditanyakan secara jelas dan tepat (Tim Hsu (2008); Annalisa Crannell (2008); Kevin P. Lee (2014); Ed. Barbeau (2015)).

Berdasarkan yang dipaparkan, melalui hasil UKPG Dindik Kota Pontianak Tahun 2016 peneliti ingin mendapatkan gambaran detail tentang penguasaan materi matematika dan kemampuan menulis penyelesaian soal matematis secara baik dan benar oleh para guru matematika dan bagaimana korelasi antara penguasaan materi dan kemampuan menulis.

\section{Metode Penelitian}

Penelitian ini menggunakan penelitian deskriptif. Menurut Sukmadinata (2011) penelitian deskriptif ditujukan untuk mendeskripsikan atau menggambarkan fenomena - fenomena atau karakteristik individual, situasi atau kelompok tertentu secara akurat, baik yang bersifat alamiah atau rekayasa manusia. Fenomena - fenomena atau karakteristik individual, situasi atau kelompok yang digambarkan bisa saja yang berlangsung saat ini ataupun saat yang lampau. Deskripsi dapat berupa pemaknaan baru terhadap kondisi, frekuensi kemunculan dari fenomena, ataupun pengkategorisasian informasi. Deskripsi bisa didapat dari hasil pengumpulan dan pengukuran data melalui pendekatan kuantitatif atau penggambaran melalui narasi melalui pendekatan kualitatif.

Untuk mendeskripsikan penguasaan materi guru matematika dan kemampuan menulis penyelesaian soal matematis guru matematika SMA dalam penelitian ini, peneliti menggunakan pendekatan kuantitatif, dimana penggambaran secara sistematis terhadap karakteristik kelompok guru matematika SMA dilakukan melalui analisis data peserta, dokumen instrumen, dan hasil UKPG Matematika Tahun 2016 Dindik Kota Pontianak yang telah diselenggarakan pada tanggal 3 Desember 2016 bertempat di SMA Negeri 1 Pontianak.

Penguasaan materi guru matematika akan dilihat dari skor nilai akhir UKPG untuk soal-soal yang terpilih dan dilihat dari daya serap butir soal yang dikelompokkan dalam lingkup materi dan level kognitif (pengetahuan-pemahaman, aplikasi, dan penalaran) untuk soal-soal terpilih. Kemampuan menulis penyelesaian soal akan dilihat dari skor menulis dan persentase kemunculan komponen menulis yang seharusnya muncul dari semua soal uraian. Skor nilai, daya serap, dan skor nilai menulis dalam penelitian ini akan dikategorisaikan menggunakan Skala Linkert untuk 4 kategori (Kemdiknas, 2010). Korelasi antara penguasaan materi dan kemampuan menulis akan dilihat berdasarkan uji statistik perbandingan dua rata-rata.

Populasi dari penelitian ini adalah semua guru matematika SMA di Kota Pontianak. Sedangkan sampel penelitian ini adalah guru matematika SMA Kota Pontianak yang mengikuti UKPG sebanyak 97 orang. Subjek penelitian ini adalah guru-guru matematika SMA Kota Pontianak yang masih aktif mengajar. Sedangkan objek penelitian adalah data, dokumen, dan hasil Uji Kompetensi Profesional Guru Matematika SMA Kota Pontianak.

Prosedur penelitian deskriptif ini akan melalui empat tahapan berikut:

\subsection{Tahap Persiapan}

Tahap persiapan penelitian meliputi : (1) kajian pustaka, (2) penyiapan format dan alat analisis dokumen, (3) pengajuan ijin lisan kepada Kepala Dinas Pendidikan Kota Pontianak; dan (4) koordinasi dengan panitia pelaksana UKPG dari unsur Dindik Kota Pontianak.

\subsection{Tahap Pengumpulan Data}

Tahap pengumpulan data meliputi: (1) pengambilan biodata peserta sesaat sebelum kegiatan UKPG dimulai, (2) peminjaman dokumen UKPG meliputi: kisi, kartu, kunci dan pendoman penskoran, perangkat soal, dan hasil validasi muka instrumen dari dinas pendidikan; dan (3) peminjaman lembar jawab UKPG.

\subsection{Tahap Pengolahan Data}


Vol 1 No 12020 Juli 2020

Jurnal AlphaEuclidEdu

Tahap pengolahan data meliputi : (1) validasi muka instrumen, (2) penskoran hasil tes soal pilihan berganda dan soal uraian, (3) analisis butir soal untuk mengukur tingkat kesukaran, indeks daya pembeda, validitas isi, dan reliabilitas skor tes, (4) seleksi soal yang akan digunakan berdasarkan analisis butir soal, (5) perhitungan skor nilai pilihan berganda, skor nilai uraian terpilih, dan skor nilai akhir (6) perhitungan persentase daya serap butir soal, daya serap per lingkup materi, dan daya serap per level kognitif, (7) analisis komponen menulis yang seharusnya muncul pada setiap soal uraian, (8) penskoran kemampuan menulis penyelesaian matematis berdasarkan komponen menulis, dan (9) analisis persentase kemunculan setiap komponen menulis.

Menggunakan format validasi muka yang diadopsi dari Safari (2008) terhadap kisi dan soal UKPG yang terdiri dari 40 soal pilihan berganda dan 5 soal uraian, didapat kesimpulan semua soal layak digunakan sebagai instrumen tes. Sesuai pedoman penskoran, setiap soal pilihan berganda yang dijawab benar mendapat skor 1 dan jawaban salah atau tidak dijawab diberi skor 0. Skor nilai maksimum setiap soal uraian berturut-turut 25, 15, 20, 15, dan 25. Analisis butir soal untuk menentukan tingkat kesukaran dan indeks daya pembeda dihitung dengan bantuan Program Anates Versi 4.0.9 (Karno dan Yuli Wibisono, 2004). Uji validitas butir soal dihitung menggunakan rumus Product Moment Pearson (Arikunto, 2013). Perhitungan reliabilitas tes soal pilihan berganda menggunakan rumus Kuder-Richardson $20\left(\mathrm{KR}_{20}\right)$ dan untuk soal uraian menggunakan rumus Koefisien Alfa Cronbach (KAC) (Safari, 2008). Uji validitas butir soal dan perhitungan koefisien reliabilitas dibantu dengan Program SPPS Statistic Version 22 (IBM, 2013).

Dari hasil pengolahan data didapat fakta bahwa rata-rata tingkat kesukaran soal pilihan berganda maupun soal uraian UKPG ada pada kategori sedang, dengan koefisien masing-masing sebesar 0,48 dan 0,31. Rata-rata indeks daya pembeda untuk soal pilihan berganda sebesar 0,48 dan soal uraian sebesar 0,61 termasuk kategori baik (Lestari \& Yudhanegara, 2015). Koefisien reliabilitas skor tes bentuk pilihan berganda sebesar 0,890 dan reliabilitas skor tes bentuk uraian sebesar 0,696 termasuk kategori tinggi dan sedang (Lestari \& Yudhanegara, 2015).

Tidak semua soal dapat dipakai dalam perhitungan nilai UKPG. Terdapat 2 soal pilihan berganda, yaitu soal nomor 1 dan 5 yang tidak dipakai dalam menentukan skor nilai UKPG mengingat indeks daya pembeda kedua soal masuk kategori buruk dan koefisien korelasi butir soal terhadap skor total juga sangat rendah. Sedangkan dari 5 soal uraian, hanya ada 3 soal yang digunakan untuk perhitungan skor nilai UKPG, sementara 2 soal lainnya, yaitu soal nomor 1 dan 3 tidak diikutkan dalam perhitungan skor nilai UKPG karena sangat rendahnya koefisien korelasi kedua butir soal terhadap skor total. Perhitungan skor nilai akhir UKPG sesuai pedoman penskoran merupakan gabungan $80 \%$ skor nilai pilihan berganda dan $20 \%$ skor nilai uraian.

Sedangkan untuk mendeskripsikan kemampuan menulis penyelesaian soal secara baik dan benar, semua soal uraian akan dianalisis. Penskoran nilai menulis dan kemunculan komponen menulis untuk setiap soal dilakukan dengan rubrik, sebagai berikut: (1) Skor 2, jika komponen tersebut muncul dengan sempurna; (2) Skor 1, jika komponen tersebut muncul tidak sempurna; dan (3) Skor 0 jika komponen menulis tersebut tidak muncul.

\subsection{Tahap Akhir}

Tahap akhir dari penelitian ini meliputi (1) penyajian hasil, (2) pembahasan, (3) penarikan kesimpulan, dan (4) penyusunan laporan penelitian.

\section{Hasil dan Pembahasan}

\subsection{Hasil Penelitian}

\subsubsection{Skor Nilai UKPG dan Menulis}

Skor nilai akhir UKPG dan skor nilai menulis dinyatakan dalam skala 0 - 100. Statistik skor nilai skor nilai akhir UKPG dan skor menulis dapat dilihat pada Tabel 1. 
Vol 1 No 12020 Juli 2020

Jurnal AlphaEuclidEdu

Tabel 1.

Skor Nilai Akhir UKPG dan Skor Nilai Menulis

\begin{tabular}{ccc}
\hline Statistik & Skor Nilai Akhir & Skor Menulis \\
\hline Rata-rata & 44,41 & 36,45 \\
\hline Maksimum & 97,90 & 95,00 \\
\hline Minimum & 12,50 & 0,00 \\
\hline Standar Deviasi & 21,342 & 27,325 \\
\hline Modus & 52,3 & 0,00 \\
\hline Persentil ke-25 & 29,20 & 15,90 \\
\hline Persentil ke-50 & 37,60 & 29,56 \\
\hline Persentil ke-75 & 55,15 & 60,90
\end{tabular}

\subsubsection{Daya Serap UKPG}

a. Daya Serap Per Lingkup Materi

Perhitungan daya serap dilakukan terhadap setiap butir soal terpilih. Kemudian soal-soal tersebut dikelompokkan berdasarkan lingkup materinya, yaitu lingkup materi aljabar, logika matematika, geometri, trigonometri, statistika-peluang, dan kalkulus. Rata-rata daya serap per lingkup materi dapat dilihat pada Diagram 1.

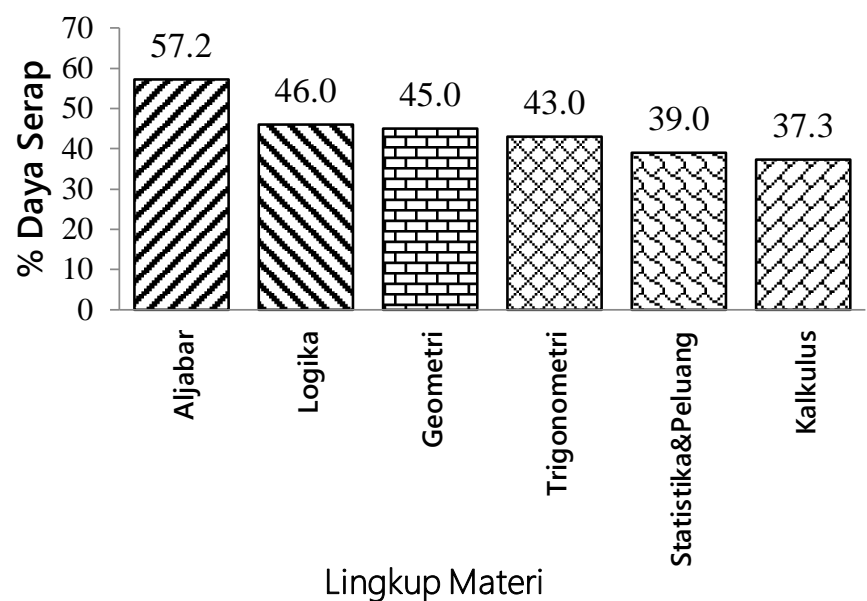

Diagram 1. Persentase Daya Serap Per Lingkup Materi

b. Daya Serap Per Level Kognitif

Soal-soal terpilih dikelompokkan berdasarkan tiga level kognitif, yaitu : pengetahuan-pemahaman, aplikasi, dan penalaran. Rata - rata nilai per level kognitif dapat dilihat pada Diagram 2 
Vol 1 No 12020 Juli 2020

Jurnal AlphaEuclidEdu

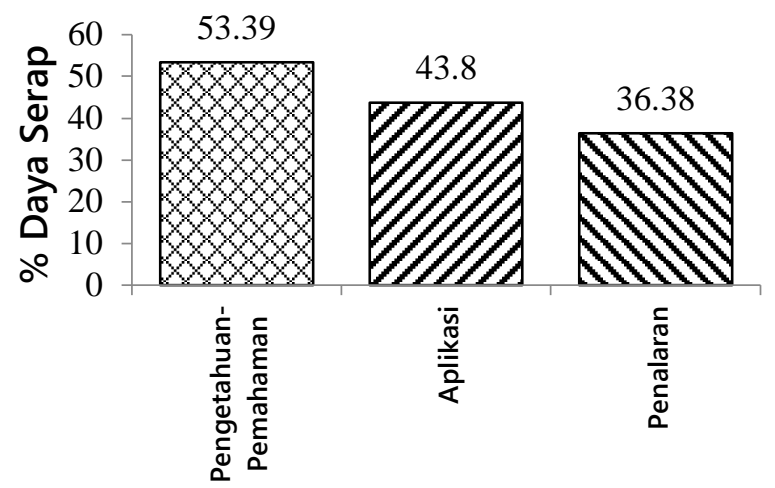

Level Kognitif

Diagram 2. Persentase Daya Serap Per Level Kognitif

\subsubsection{Persentase Kemunculan Setiap Komponen Menulis}

Persentase kemampuan menulis setiap komponen menulis sesuai karakteristik dari semua soal uraian dapat dilihat pada Diagram 3.

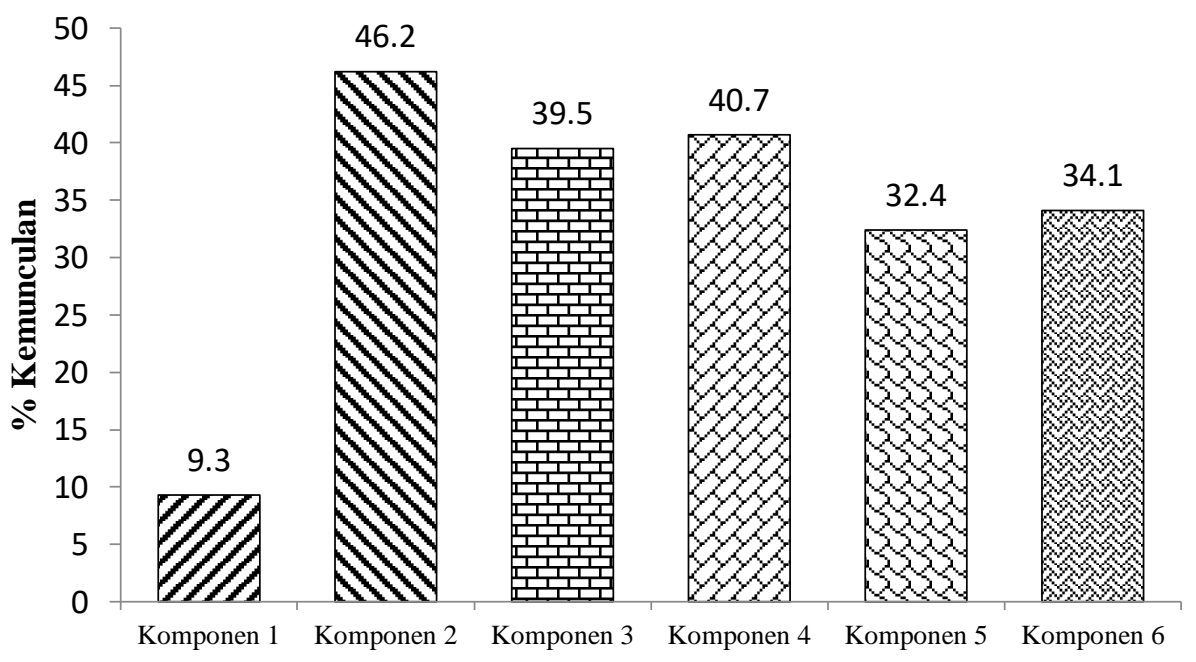

Komponen Menulis Penyelesaian Soal

Diagram 3. Persentase Kemunculan Setiap Komponen Menulis

\subsection{Pembahasan}

\subsubsection{Penguasaan Materi Guru Matematika Berdasarkan Skor Nilai UKPG}

Rata-rata nilai akhir UKPG Matematika SMA Kota Pontianak sebesar 44,41 masuk dalam kategori rendah. Hasil UKPG ini hampir sama dengan hasil penelitian Fahmi (2011) dengan rata-rata hasil tes matematika terhadap 630 guru matematika yang tersebar di 21 provinsi dan 100 kabupaten/kota di Indonesia, yaitu sebesar 44,64. Jika ditelaah lebih lanjut, terdapat 12 guru $(12,37 \%)$ yang tidak menjawab atau tidak sempat menjawab 
Vol 1 No 12020 Juli 2020

Jurnal AlphaEuclidEdu

soal uraian dan sebanyak 73 orang guru $(75,28 \%)$ mempunyai nilai di bawah 55 . Hanya ada 14 orang guru $(16,49 \%)$ yang mempunyai nilai sama atau lebih dari 75 . Hasil ini juga tidak jauh berbeda dengan penelitian Tatag Yuli Eko Siswono (2010) dimana 79\% guru matematika yang diteliti mendapatkan skor nilai di bawah 50 .

Banyaknya guru yang tidak menjawab soal uraian atau memperoleh nilai di bawah 50, dapat menjadi indikasi bahwa kecepatan guru-guru tersebut dalam menyelesaikan soal masih rendah padahal tingkat kesukaran soal pada kategori sedang. Standar waktu bagi peserta didik dalam menyelesaikan soal UN rata-rata adalah tiga menit per soal, karena soal UN matematika sebanyak 40 soal harus bisa diselesaikan dalam waktu 120 menit. Selain faktor kecepatan dalam mengerjakan soal, faktor usia, faktor waktu lama mengajar, dan faktor jurusan apa diajar juga mempengaruhi nilai akhir UKPG dengan tingkat signifikansi variatif.

Melalui analisis perbandingan dua rata-rata dengan metode ANOVA Satu Arah diketahui bahwa: (1) Kelompok usia peserta berpengaruh terhadap nilai UKPG walaupun pengaruhnya tidak terlalu besar karena tingkat signifikansinya hanya 0,366; (2) Lama mengajar para guru mempengaruhi nilai UKPG dengan tingkat signifikansi 0,615 . Tetapi tidak ada perbedaan yang signifikan antara guru yang baru mengajar selama setahun dengan yang sudah mengajar lebih dari satu tahun; dan (3) Pengalaman mengajar di jurusan IPA saja (Kelompok 1), mengajar jurusan IPA dan IPS (Kelompok 2), atau mengajar jurusan IPS saja (Kelompok 3) berbeda nyata terhadap nilai akhir UKPG. Guru Kelompok 1 dan Kelompok 2 mempunyai nilai akhir UKPG berbeda nyata terhadap guru matematika Kelompok 3. Selisih rata-rata nilai antara guru Kelompok 1 dengan guru Kelompok 3 sebesar 22 point. Sedangkan selisih rata-rata nilai antara guru matematika Kelompok 2 dengan guru Kelompok3 sebesar 15 point. Tidak ada perbedaan signifikan antara guru Kelompok 1 dan guru Kelompok 2 dengan selisih rata-rata nilai kedua kelompok hanya 7 point.

\subsubsection{Penguasaan Materi Guru Matematika Berdasarkan Daya Serap}

\section{a. Berdasarkan Daya Serap Butir Soal}

Rata-rata daya serap butir soal UKPG sebesar $47 \%$ ada pada kategori rendah. Daya serap paling tinggi sebesar $89 \%$ ada pada materi operasi matriks, dengan indikator soal menentukan hasil kali perkalian matriks. Daya serap paling rendah sebesar $24 \%$ ada pada materi kurva irisan kerucut, dengan indikator menggunakan sifat parabola untuk menyelesaikan masalah. Hasil ini menunjukkan penguasaan materi matematika oleh guru matematika SMA Kota Pontianak secara keseluruhan masih rendah.

b. Berdasarkan lingkup materi

Tidak ada lingkup materi yang daya serapnya masuk dalam kategori tinggi. Daya serap lingkup materi aljabar $(57,2 \%)$ hanya pada kategori sedang. Sedangkan daya serap lingkup materi logika matematika (46\%), geometri (45\%), dan trigonometri (43\%) masuk dalam kategori rendah. Untuk materi statistika - peluang (39\%) dan materi kalkulus (37,3\%) masuk dalam kategori sangat rendah. Hasil penelitian ini mirip dengan hasil penelitian Yulia Lingustika dkk (2011).

c. Berdasarkan level kognitif

Berdasarkan uji statistik terhadap daya serap soal pilihan berganda yang dikelompokkan berdasarkan level kognitif pengetahuan-pemahaman, aplikasi, dan penalaran ada perbedaan yang signifikan antara level kognitif. Perbedaan signifikan terjadi pada level penalaran terhadap level pengetahuan-pemahaman. Sedangkan penguasaan guru pada soal level pengetahuan -pemahaman tidak berbeda dengan level aplikasi. Demikian juga tidak ada perbedaan antara penguasaan guru pada soal level aplikasi dan level soal penalaran.

Dari Diagram 2 terbaca rata-rata daya serap untuk soal level pengetahuan-pemahaman adalah yang tertinggi sebesar 53,59\%, sedangkan rata-rata daya serap soal penalaran hanya 36,38\%. Artinya guru matematika mengalami kesulitan lebih pada level penalaran dibandingkan pada soal-soal pengetahuanpemahaman. Sedangkan penguasaaan soal aplikasi tidak berbeda signifikan terhadap soal level pengetahuan- 
Vol 1 No 12020 Juli 2020

Jurnal AlphaEuclidEdu

pemahaman dan level penalaran, walaupun rata-rata daya serap soal aplikasi sebesar $43,80 \%$ terlihat berbeda dengan kedua level lainnya.

\subsubsection{Skor Nilai Menulis}

Rata-rata skor nilai menulis penyelesaian soal matematis guru matematika SMA Kota Pontianak adalah sebesar 36,45 masuk kategori rendah. Mencermati lembar jawaban dari para peserta UKPG terdapat 12 guru (12,37\%) yang tidak menjawab soal uraian sehingga skor nilai menulisnya nol dan mempengaruhi rata-rata nilai menulis guru- guru tersebut. Terdapat sebanyak 63 guru (64,9\%) mendapat skor nilai menulis kurang dari 47,5 dan hanya sebanyak 13 guru $(13,4 \%)$ yang mendapat skor nilai menulis lebih dari 71,1 . Hasil ini menunjukkan bahwa kemampuan menulis penyelesaian soal sebagian besar guru matematika masih rendah. Belum adanya penelitian sejenis, membuat komparasi hasil penelitian ini belum dapat dilakukan. Pada saat pelaksanaan UKPG, para guru tidak diinformasikan untuk menuliskan komponen dan langkah-langkah penyelesaian soal secara lengkap. Hal ini bisa menjadi salah keterbatasan dari penelitian ini, tetapi bisa juga menjadi kelebihan dari penelitian ini dimana kita bisa mendapat gambaran tentang kesadaran guru dalam menuliskan langkahlangkah penyelesaian soal uraian seperti yang selama ini dituntutkan untuk dilakukan para peserta didik. Menuliskan komponen secara baik dan benar dalam penyelesaian soal uraian seharusnya sudah mendarah daging bagi seorang guru, terutama bagi guru matematika, karena ini menjadi praktek pembelajaran sehari-hari di kelas. Temuan ini dapat menjadi informasi awal tentang kemampuan menulis para guru matematika dan dapat menjadi jalan masuk bagi penelitian-penelitian lebih lanjut.

\subsubsection{Kemampuan Menulis Penyelesaian Soal Per Komponen}

Persentase Komponen 1, yaitu komponen menuliskan kembali fokus pertanyaan dari soal yang ditanyakan hanya sebesar 9,3\%. Analisis kemunculan Komponen 1 ini hanya dilakukan pada soal nomor 2 saja. Dengan persentase sebesar 9,3\% dapat dikatakan hampir semua guru matematika SMA dalam menjawab soal uraian nomor 2 tidak menuliskan kembali fokus pertanyaan dari soal yang ditanyakan. Sebagian besar guru langsung menuliskan yang diketahui dan menuliskan proses pengerjaan soal.

Persentase Komponen 5, yaitu komponen menuliskan langkah penyelesaian soal secara tepat dan jelas hanya sebesar 32,4\%. Analisis komponen menuliskan langkah penyelesaian secara tepat dan logis dilakukan pada seluruh soal uraian, karena menuliskan langkah penyelesaian memang selayaknya muncul untuk setiap soal uraian. Sebagai contoh penyelesaian soal nomor 1 yang tidak tepat dan tidak logis, seperti ditunjukkan Gambar 1 .

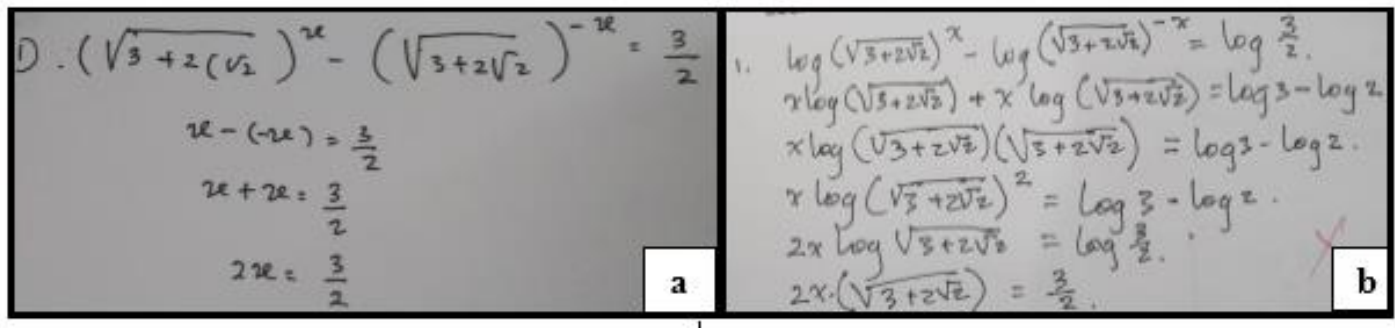

Gambar 1. Penulisan langkah penyelesaian soal yang salah dan tidak logis.

Kesalahan seperti tersaji pada Gambar 1, termasuk kesalahan fatal yang sangat mengusik, dimana peserta yang bersangkutan tidak paham cara menyelesaikan soal persamaan eksponen. Penggunaan operasi logaritma seperti Gambar 1b pada persamaan adalah langkah yang salah. Selain itu masih ada guru yang mengalami masalah pada hal mendasar dalam logaritma, yaitu kesalahan menuliskan hubungan yang tepat antara bentuk eksponen dan bentuk logaritma. Paparan dari penyelesaian soal uraian nomor 1 semakin menguatkan dugaan 
Vol 1 No 12020 Juli 2020

Jurnal AlphaEuclidEdu

bahwa penguasaan terhadap materi logaritma oleh guru matematika masih memprihatinkan. Hal ini sejalan dengan sangat rendahnya daya serap soal dengan indikator menggunakan konsep logaritma untuk menyelesaiakn soal yang hanya $37 \%$ dari penelitian ini.

Persentase Komponen 6, yaitu komponen menuliskan kesimpulan jawaban dari soal yang ditanyakan hanya sebesar $34,1 \%$. Analisis terhadap kemampuan menuliskan kesimpulan jawaban dilakukan pada soal nomor 2, 3, 4, dan 5. Sebagai contoh pada penyelesaian soal nomor 2 dan 3, ada peserta yang tidak menerjemahkan kembali makna dari nilai variabel yang sudah berhasil ditentukan dalam penyelesaian soal dan hanya dibiarkan begitu saja. Kekurangan ini dapat dilihat pada Gambar 2.

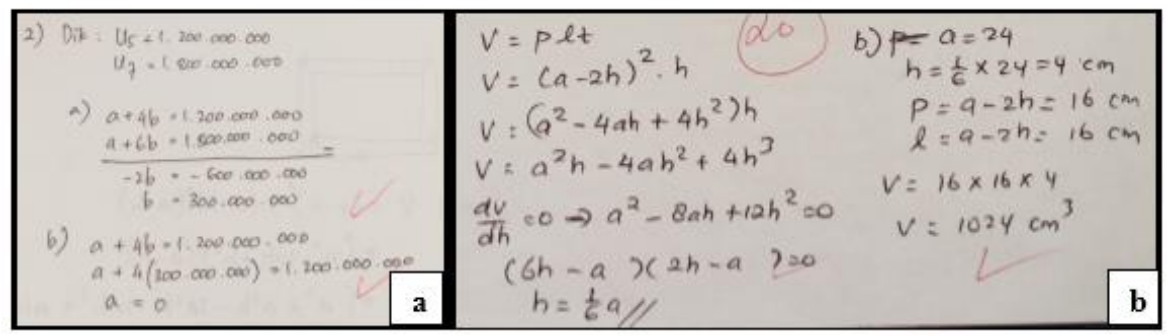

Gambar 2. Penyelesaian soal yang tidak disertai kesimpulan jawaban dari soal yang ditanyakan.

Persentase kemunculan Komponen 3, yaitu komponen menuliskan ekspresi matematis atau hubungan informasi secara tepat hanya sebesar $39,5 \%$ yang dapat diartikan sebagian besar guru matematika SMA tidak menuliskan hubungan informasi atau ekspresi matematis secara tepat. Analisis komponen menulis hubungan informasi ini dilakukan terhadap semua soal uraian. Kekurangan yang ditemukan misalnya penulisan notasi untuk suku ke-n dituliskan dengan simbol jumlah suku-n atau pernyataan ukuran dimensi kotak yang tidak sesuai dengan informasi yang diberikan, seperti tersaji pada Gambar 3.

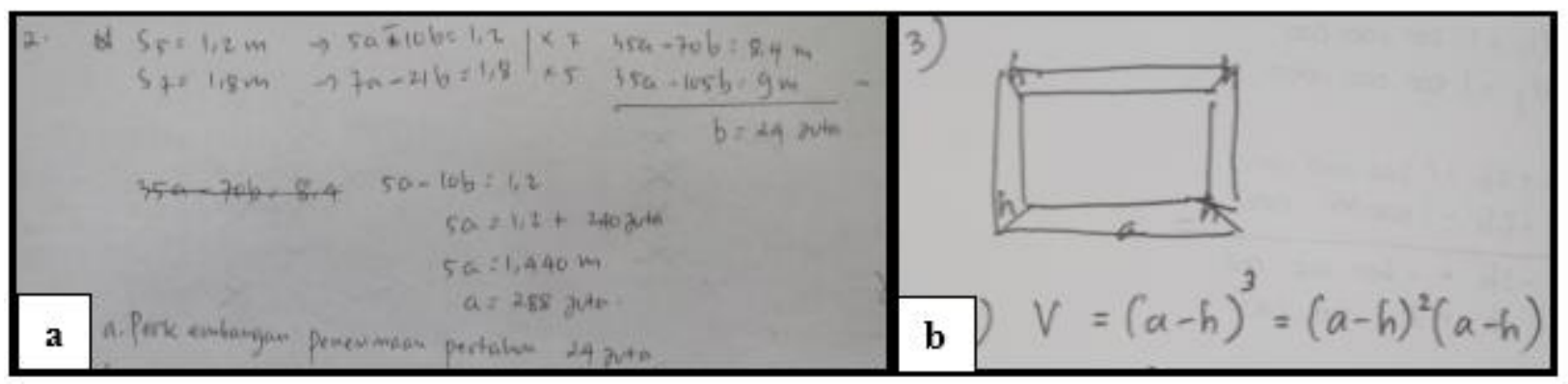

Gambar 3. Penulisan hubungan informasi dan penulisan ekspresi matematis yang tidak tepat.

Dari Gambar 3a, tampak ada guru yang masih mengalami kesalahan dalam menerjemahkan informasi yang seharusnya tentang suku ke-n deret aritmatika, tetapi dituliskan menjadi jumlah $\mathrm{n}$ suku pertama deret aritmatika dan tidak tepat. Gambar 3b menunjukkan kesalahan menerjemahkan dimensi kotak yang diberikan dalam soal nomor 3, di mana diketahui selembar karton berbentuk persegi dengan panjang sisi a yang digunting keempat pojoknya dengan bentuk persegi ukuran h, diterjemahkan seperti pada Gambar $3 b$.

Persentase kemunculan Komponen 4, yaitu komponen menyajikan gambar dengan jelas atau lengkap atau tepat hanya sebesar 40,7\%. Analisis komponen ini terbaca dari analisis terhadap penulisan jawaban untuk nomor 3 dan 5. Hal ini dapat dimaknai bahwa sebagian besar guru dalam menyajikan gambar masih belum jelas atau belum tepat. Sebagai contoh mencolok adalah ada guru yang tidak konsisten dalam menuliskan urutan nama titik sudut pada kubus ABCD.EFGH dalam menyelesaikan soal nomor 5. Penulisan titik sudut yang tidak konsisten menyebabkan kekaburan dalam menyatakan kembali pertanyaan yang diajukan. Kekurangan dalam penyajian gambar juga menampakkan kesulitan bahkan miskonsepsi beberapa guru tentang sudut antara dua 
Vol 1 No 12020 Juli 2020

Jurnal AlphaEuclidEdu

garis bersilangan. Hali ini tampak pada uraian nomor 5 yang merupakan soal lingkup geometri dimana diketahui titik $\mathrm{P}$ titik tengah dari rusuk $\mathrm{BF}$, titik $\mathrm{Q}$ merupakan titik tengah rusuk $\mathrm{CD}$, serta $\mathrm{R}$ titik tengah dari rusuk AD. Pertanyaannya adalah menentukan nilai sinus sudut yang terbentuk antara garis EP dan garis RQ. Kekurangan penyajian gambar, kesulitan penentuan sudut, dan miskonsepsi beberapa peserta dalam menjawab soal nomor 5 disajikan dalam Gambar 4.

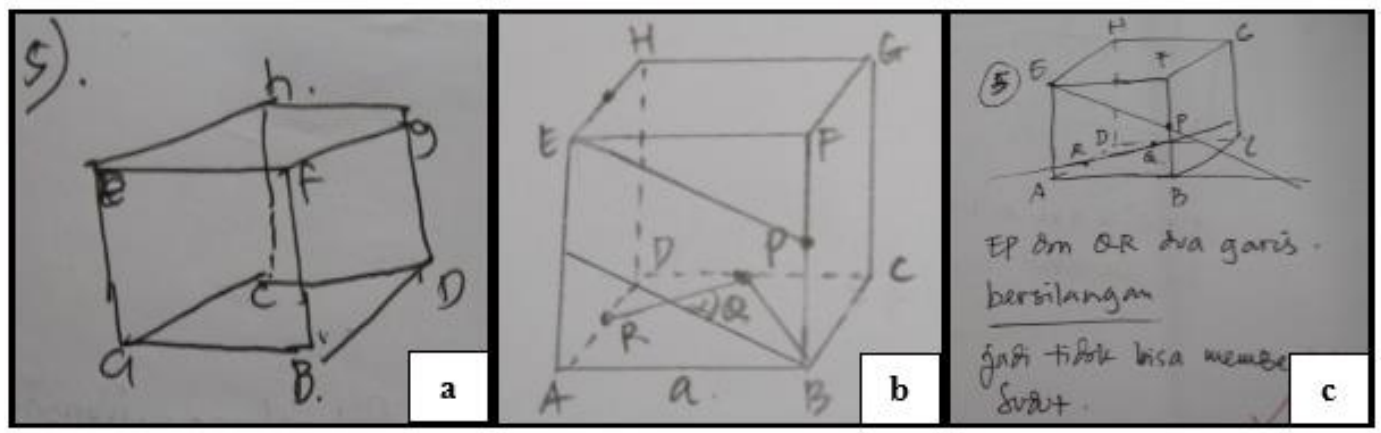

Gambar 4. Penyajian gambar yang tidak jelas dan konsep yang keliru.

Kesalahan seperti ini semakin memperjelas adanya kesulitan guru matematika pada lingkup materi geometri dimana daya serap untuk lingkup materi geometri hanya pada kisaran 45,0\% pada penelitian ini. Walaupun beberapa peserta masih mengalami kesulitan dalam kemampuan spasial, tetapi beberapa peserta lain dengan nilai UKPG yang masuk kategori tinggi, dapat menyelesaikan soal yang sama dengan baik bahkan dengan pendekatan yang berbeda. Pendekatan yang cukup mencolok perbedaannya dengan cara biasanya adalah penggunaan konsep sudut antara dua vektor, dimana dua garis bersilangan dalam ruangan dipandang sebagai sudut antara dua vektor dalam ruang.

Persentase kemunculan Komponen 2, yaitu mendefinisikan variabel yang digunakan secara jelas dan tepat hanya sebesar 46,21\%. Kemunculan Komponen 2 dideteksi pada soal nomor 1, 2, 4, dan 5. Hasil ini mencerminkan bahwa sebagian besar guru tidak mendefinisikan variabel yang digunakan secara jelas. Contohnya dalam menyelesaikan soal uraian nomor 2 yang berkaitan dengan deret aritmatika, kebanyakan guru langsung menulis langkah penyelesaian dan menganggap sudah lazim huruf a untuk melambangkan suku pertama dan huruf $b$ untuk melambangkan beda deret aritmatika. Ketidakjelasan dalam pendefinisian variabel selain membinggungkan, kadang berakibat fatal dan menuntun guru pada kesalahan yang tidak perlu. Soal yang seharusnya menggunakan konsep deret aritmatika, tetapi yang terjadi justru diselesaikan dengan konsep deret geometri. Hal ini mungkin berkaitan dengan daya serap soal dengan indikator menggunakan deret geometri dalam menyelesaikan masalah untuk penilitian ini hanya pada angka $37 \%$. Kekurangan ini seperti tampak pada Gambar 5.

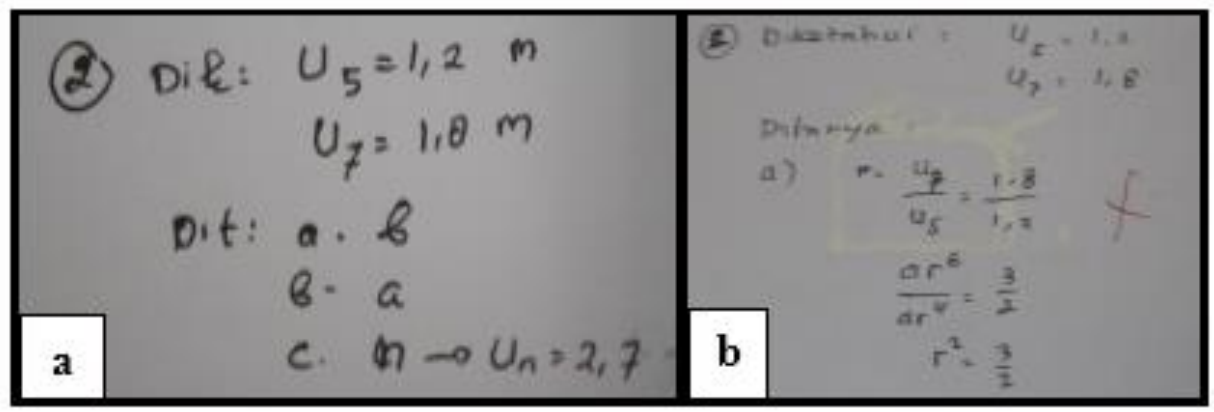

Gambar 5. Penulisan definisi variabel yang tidak jelas 
Vol 1 No 12020 Juli 2020

Jurnal AlphaEuclidEdu

\subsubsection{Hubungan Penguasaan Materi dan Kemampuan Menulis Penyelesaian Soal}

Berdasarkan uji statistik perbandingan dua rata-rata dengan menggunakan Program SPSS ANOVA Satu Arah, didapat signifikansi kurang dari 0,05, maka dapat disimpulkan ada perbedaan yang nyata antara tingkat penguasaan materi matematika dengan kemampuan menulis guru matematika SMA. Semakin tinggi nilai akhir UKPG semakin tinggi juga nilai menulis. Beberapa guru dengan nilai akhir UKPG di bawah 50, mengalami kesulitan dalam menjawab soal sudut antara dua garis bersilangan dalam ruang, yang mana materi ini termasuk materi yang cukup kompleks dan menjadi momok bagi peserta didik dalam memahaminya maupun bagi guru dalam mengajarkannya. Tetapi untuk beberapa guru dengan skor nilai di atas 71,1 mampu menyelesaikan soal tersebut dan beberapa di antaranya mampu menyelesaikan soal tersebut dengan pendekatan berbeda menggunakan konsep sudut antara dua vektor dalam ruang. Dengan demikian dapat ditarik kesimpulan semakin tinggi tingkat penguasaan materi, semakin tinggi pula kemampuan menulis guru matematika SMA. Hal ini semakin menguatkan hipotesis tentang adanya hubungan linear antara penguasaan materi dan kemampuan menulis penyelesaian soal.

\section{Kesimpulan}

Dari hasil penelitian dan pembahasan dapat disimpulkan:

1. Sebanyak $75,28 \%$ guru mempunyai skor nilai akhir UKPG kurang dari 55 dan sebanyak $13,9 \%$ mempunyai skor nilai akhir UKPG di atas 76,4.

2. Penguasaan materi guru matematika SMA masuk kategori rendah dengan rata-rata daya serap butir soal sebesar $47 \%$. Daya serap terendah ada pada lingkup materi kalkulus dan daya serap tertinggi pada lingkup materi aljabar. Berdasarkan level kognitif, daya serap terendah pada level penalaran dan tertinggi ada pada level pengetahuan-pemahaman.

3. Sebanyak $64,9 \%$ guru mempunyai skor nilai menulis penyelesaian soal matematis kurang dari 47,5 dan sebanyak 13,4\% guru mendapat skor nilai menulis lebih dari 71,1 .

4. Komponen menulis paling rendah adalah komponen menuliskan kembali fokus pertanyaan, dan paling tinggi adalah komponen mendefinisikan variabel secara jelas dan tepat.

5. Semakin tinggi tingkat penguasaan materi, semakin tinggi kemampuan menulis penyelesaian soal matematis para guru.

\section{Referensi}

Arifani, Nurul Hidayati., As'ari Abdur Rahman., Abdiyo . (2016). Kesalahan Siswa Dalam Menyelesaikan Soal Matematika TIMSS Menurut Teori Newman : Studi Kasus Pada Siswa Kelas VIII SMP Negeri 1 Tanjungbumu Bangkalan. Makalah disajikan pada Seminar Nasional Matematika dan Pendidikan Matematika UNY.

Arikunto, Suharsimi. (2013). Dasar-Dasar Evaluasi Pendidikan. Jakarta: PT.Bumi Aksara.

Badan Standar Nasional Pendidikan. (2006) . Standar Kompetensi dan Kompetensi Dasar KTSP 2006. Jakarta : Kemdikbud . (2016) . Prosedur Operasional Standar Ujian Nasional dan Ujian Sekolah Tahun Pelajaran 2016/2017. Jakarta : Kemdikbud

Ball, D. L., Thames, M. H., \& Phelps, G. (2008). Content knowledge for teaching: What makes it special? Journal of Teacher Education, 59(5).389. DOI: 10.1177/0022487108324554

Barbeau , Ed .(2015). Writing Up Solutions. Toronto : Mathematics, University of Toronto [Online]. http://www.math.toronto.edu/cms/math/school-math/math-olymon. diakses 12 Desember 2016

Campbell et. al. (2014). Journal for Research in Mathematics Education, Vol. 45, No 4: Reston, VA: NCTM

Crannell, Annalisa. (2008) . A Guide to Writing in Mathematics Classes, [Online] http://www.math.cornell.edu/ projcalc/fall2001/projects/projguide.pdf diakses 20 Desember 2016 
Vol 1 No 12020 Juli 2020

Jurnal AlphaEuclidEdu

Departemen Pendidikan Nasional. (2006). Peraturan Menteri Pendidikan Nasional Nomor 22 Tahun 2006 tentang Standar Isi Kurikulum 2006 . Jakarta : Depdiknas

Departemen Pendidikan Nasional. (2007). Peraturan Menteri Pendidikan Nasional Nomor 16 Tahun 2007 tentang Standar Kualifikasi Akademik dan Kompetensi Guru . Jakarta : Depdiknas

Fahmi (2011), Kemampuan Penguasaaan Materi Pelajaran Guru SMA/MA Berdasarkan Hasil Ujian Nasional Rendah, Jakarta : Pusat Penelitian Pendidikan Balitbang Kemdikbud.

Hill, Rowan, dan Ball. (2004). Effects of Teachers' Mathematical Knowledge for Teaching on Student Achievement, San Diego, CA: American Educational Research Association.

Horizon Research, Inc. (2008). Deepening Teacher Content Knowledge. Math and Science Partnership (MSP) Projects. Chapel Hill, North Carolina : HRI.

International Business Machines .(2013). Program SPSS Statistic Version 22. United States: IBM

Karno To dan Wibisono, Yuli . (2004). Program Anates Versi 4.0.9. Bandung : Pengarang.

Krathwohl, D.R.(2002). A Revision of Bloom's Taxonomy: An Overview. Theory in Practice, 41.

Kementerian Pendidikan Nasional. (2010). Petunjuk Teknis Penyusunan Perangkat Penilaian Afektif di Sekolah Menengah Atas, Jakarta : Direktorat Pembinaan SMA

Kementerian Pendidikan dan Kebudayaan . (2013). Peraturan Menteri Pendidikan dan Kebudayaan Nomor 64 Tahun 2013. Jakarta: Kemdikbud.

Nomor 54 Tahun 2013. Jakarta: Kemdikbud.

(2013). Peraturan Menteri Pendidikan dan Kebudayaan

Kementerian Pendidikan dan Kebudayaan . (2014). Peraturan Menteri Pendidikan dan Kebudayaan Nomor 160 Tahun 2014 tentang Pemberlakukan Kurikulum 2006 dan Kurikulum 2013. Jakarta : Kemdikbud . (2016). Hasil UKG 2015. Jakarta : Kemdikbud

(2016). Peraturan Menteri Pendidikan dan Kebudayaan

Nomor 21 Tahun 2016 tentang Standar Isi, Jakarta: Kemdikbud.

Lee, Kevin P . (2014) . A Guide to Writing Mathematics . [Online] http://web.cs.ucdavis.edu/ amenta/w10/writingman.pdf diakses 20 Desember 2016

Lestari, Karunia Eka dan Yudhanegara, Mokhammad Ridwan. (2015) Penelitian Pendidikan Matematika, Bandung : PT. Refika Aditama.

Linguistika, Yulia., Listiyani, Endang., Retnawati, Heri., (2013) Peta Penguasaan Materi Matematika Guru SMA dan Hubungannya Dengan Prestasi Belajar Siswa, Makalah dipresentasikan dalam Seminar Nasional Matematika dan Pendidikan Matematika, tanggal 9 November 2013 di Jurusan Pendidikan Matematika FMIPA Universitas Negeri Yogyakarta.

Manibuy, Ronald., Mardiyana, Saputro, Dewi Retno Sari.(2014). Analisis Kesalahan Siswa dalam Menyelesaikan Soal Persamaan Kuadrat Berdasarkan Taksonomi SOLO pada Kelas X SMA Negeri 1 Plus di Kabupaten Nabire-Papua. Jurnal Elektronik Pembelajaran Matematika Vol.2.No.9 Hal.933-945: PPs Universitas Sebelas Maret Surakarta.

National Council of Teachers of Mathematics (2000). Principles and Standards for School Mathematics. Reston, VA: NCTM.

National Mathematics Advisory Panel. (2008). Foundations for Success: The final report of the National Mathematics Advisory Panel. Washington, DC : U.S. Department of Education.

Pusat Pengembangan dan Pemberdayaan Pendidik dan Tenaga Kependidikan (P4TK) Matematika. (2016). Kebijakan Pengembangan dan Pembinaan Karir Guru, Yogyakarta: Kemdikbud.

Safari. (2008). Penulisan Butir Soal Berdasarkan Kurikulum Tingkat Satuan Pendidikan (KTSP). Jakarta: Asosiasi Pengawas Sekolah Indonesia (APSI).

Safari. (2008). Analisis Butir Soal. Jakarta: Asosiasi Pengawas Sekolah Indonesia (APSI).

Siswono, Tatag (2010). Profesi Guru Matematika dan Problematika yang Dihadapi Makalah disampaikan pada Seminar Nasional di Universitas Lambung Mangkurat tanggal 4 Desember 2010, Banjarmasin. 
Vol 1 No 12020 Juli 2020

Jurnal AlphaEuclidEdu

Sukmadinata, Nana Syaodih. (2011). Metode Penelitian Pendidikan. Cetakan ke 7. Bandung : Remaja Rosdakarya.

Tim Shu (2008). Writing math in paragraph style . San Jose: San Jose University. [online] Tersedia. http://www.toroidal snark.net/timhsuwriting.pdf diakses 12 Desember 2016

Urquhart, Vicki. (2007). Using Writing in Mathematics to Deepen Student Learning: Denver, Colorado : McRel

Wibowo, Rohmad Ari. (2016). Peningkatan Kemampuan Koneksi Matematika dengan Strategi Problem Based Learning di SMK. Skripsi. Jurusan Pendidikan Matematematika, FKIP, Universitas Muhammadiyah Surakara. 
